\title{
Blockchain and Smart Contracting for the Shareholder Community
}

\author{
Christoph Van der Elst ${ }^{1,2} \cdot$ Anne Lafarre $^{3}$
}

Published online: 19 February 2019

(c) The Author(s) 2019

\begin{abstract}
Current shareholder engagement systems face large classical inefficiencies. First, due to the large chains of intermediaries in the current securities models, transaction costs are high and shareholder votes and other information are not always correctly transmitted between shareholders and issuers. Recent cases including DNick Holding and T. Rowe Price show the 'absurdness' of the current systems. The Shareholder Rights Directive II addresses these problems and the Implementing Regulation already hints at modern technologies to increase the transparency and verifiability of shareholder engagement. Next, the current shareholder engagement system enables different opportunities for different types of shareholders, creating inequalities and hindering shareholder democracy. The solution to these substantial problems lies in a state-of-the-art technology: in this contribution we argue that blockchain technology can solve these current inefficiencies that shareholders and companies face. Using a permissioned blockchain, information can be stored in a verifiable and immutable way, with a consensus mechanism tailored to its purpose. The large amount of initiatives and prototypes of blockchain proxy voting and trading, including the legislative initiatives that were initiated in the past 2 years, show the merits of using this state-of-the-art technology. The Europe Union should incorporate this technology in its legislation, like the CSD regulation, for remaining technology-proof in this globalized market.
\end{abstract}

Keywords Shareholder rights · Shareholder voting $\cdot$ Shareholder engagement · General meeting $\cdot$ Blockchain $\cdot$ Distributed ledger technology

Christoph Van der Elst

c.vdrelst@uvt.nl

Anne Lafarre

a.j.f.lafarre@uvt.nl

1 Professor of Business Law and Economics, Tilburg University, Tilburg, The Netherlands

2 Professor of Business Law and Economics, Ghent University, Ghent, Belgium

3 Assistant Professor of Business Law, Tilburg University, Tilburg, The Netherlands 


\section{Introduction}

The exercise of shareholder rights currently requires the involvement of many intermediaries, regularly resulting in inefficiencies, mistakes and costly court cases. DNick Holding, a UK Plc with its management and operations in Germany and traded on the Deutsche Börse, provides a textbook example. ${ }^{1}$ When DNick's Annual General Meeting of shareholders (hereinafter: 'AGM') approved the resolutions to cancel the listing and to convert into a private limited company, a group of minority shareholders started an appraisal procedure to cancel the resolution and to receive a fair price for their shares. However, the shareholder register only included two shareholders: the CEO and the Bank of New York Depository (Nominees) Ltd (hereinafter: 'BNY'). BNY, as the common depository agent, held the shares on trust for the account holders with Clearstream, which is the central securities depository (hereinafter: 'CSD') subsidiary of Deutsche Börse. These account holders of Clearstream, including banks and financial institutions, and no individuals, hold so-called 'Clearstream Interests' or 'CIs'. ${ }^{2}$ These CIs are traded on the Deutsche Börse. The minority shareholders of DNick Holding that started an appraisal procedure were customers of these banks, and not members of the company in accordance with section 112(2) of the UK Companies Act ('CA'), stating that '[e]very other person who agrees to become a member of a company, and whose name is entered in its register of members, is a member of the company'. Moreover, according to DNick's articles of association, holders of an account with Clearstream, i.e. banks and financial institutions, were allowed to vote or appoint a proxy to vote for them. Since these holders of CIs voted in favour of the cancelling of the listing and the conversion, the application to the court for the cancellation of the resolution pursuant to section $98 \mathrm{CA}$ 2006 was not open. Consequently, the minority shareholders of DNick Holding saw their appraisal case dismissed and the court confirmed the AGM resolutions.

Shareholders on the other side of the Atlantic encountered similar experiences. Michael Dell made the company Dell Inc. private through a merger agreement, valuing the company close to $\$ 25$ billion. Not all shareholders supported the privatization, believing that Dell and the private equity firm, Silver Lake Partners, were undervaluing the company. Some shareholders, including T. Rowe Price \& Associates and institutions that relied on T. Rowe Price \& Associates to direct the voting of their shares (together referred to as 'T. Rowe'), requested an appraisal of the fair value of their shares. Similar to the aforementioned UK case, using this right requires shareholders not to have voted in favour of the merger consideration nor consented thereto in writing (section 262 Delaware General Corporation Law, 'DGCL'). T. Rowe's vote was carried out through a complex chain of intermediaries. ${ }^{3}$ More specifically, Cede \& Co (hereinafter: 'Cede') was the holder of record of T. Rowe's shares under

\footnotetext{
${ }^{1}$ Eckerle \& Ors v. Wickeder Westfalenstahl GmbH [2013] EWHC (Ch) 68.

2 Ibid., para. 14(c).

${ }^{3}$ Re Appraisal of Dell Inc., No. C.A. 9322-VCL, 2016 (Del. Ch. May 11, 2016).
} 
Delaware law, ${ }^{4}$ but State Street Bank \& Trust Company (hereinafter: 'State Street') had the voting authority as the custodian. In turn, State Street outsourced this task to Broadridge Financial Solutions (hereinafter: 'Broadridge') by authorizing Broadridge to execute proxies on State Street's behalf. Also in turn, T. Rowe relied on Institutional Shareholder Services (hereinafter: 'ISS') for notifying T. Rowe about general meetings, issuing voting recommendations, collecting voting instructions and conveying these instructions to Broadridge. However, while T. Rowe instructed ISS to vote against the Dell merger, an error was made in the chain of intermediaries in proxy voting, resulting in voting in favour of the merger. ${ }^{5}$ As a result, T. Rowe was not able to benefit from the fair price ruling in the appraisal procedure. ${ }^{6}$

In a keynote address for the Council of Institutional Investors, vice-chancellor Laster called the Delaware system 'absurd' ${ }^{7}$ arguing that blockchain technology can be considered the solution. Also the European Commission (hereinafter the 'EC') acknowledges the problems resulting from the intermediated system for the exercise of shareholder rights. The Shareholder Rights Directive II ${ }^{8}$ (hereinafter: 'SRD II') needs to foster the development of long-term relationships between the shareholders and the company and facilitates the exercise of shareholder rights and shareholder engagement. Reaching these goals, the SRD II, inter alia, contains new provisions for (i) the identification of shareholders, (ii) the transmission of information between shareholders and the issuer, and (iii) the exercise of shareholder voting rights. ${ }^{9}$ The Implementing Regulation ${ }^{10}$ encourages the use of modern technologies (preamble 4), paving the way for the use of blockchain technology.

\footnotetext{
${ }^{4}$ Cede is the nominee of the Depository Trust Company ('DTC'), which is in turn the central securities depository subsidiary of the Depository Trust and Clearing Corporation ('DTCC').

${ }^{5}$ T. Rowe made use of an automated system that generated default voting instructions to ISS, which was a yes vote in the case of a management-supported merger. The shareholder meeting in July was adjourned three times. On 4 September 2013 the ISS voting system generated a new meeting record for the re-scheduled meeting. Whereas the T. Rowe voting system showed both the meeting record for the July meeting and the September meeting, in the ISS voting system the September meeting record replaced the July meeting record. Since instructions from T. Rowe's voting policy were automatically uploaded in the September meeting record, resulting in a vote in favour of the merger, the ISS proxy system only contained this default voting instruction. For more information, see Re Appraisal of Dell Inc., Opinion No. C.A. 9322-VCL, 2016 (Del. Ch. May 11, 2016). See for another example Lafarre and Van der Elst (2018).

${ }^{6}$ Re Appraisal of Dell Inc., Memorandum Opinion No. C.A. 9322-VCL, 2016 (Del. Ch. May 31, 2016). T. Rowe decided to pay $\$ 194$ million to compensate its clients for this proxy voting error. See T. Rowe Price Group (2016).

${ }^{7}$ Laster (2016), p 7.

${ }^{8}$ Directive (EU) 2017/828 of the European Parliament and of the Council of 17 May 2017 amending Directive 2007/36/EC as regards the encouragement of long-term shareholder engagement [2017] OJ L132/60.

${ }^{9}$ Art. 3a(1) adds that Member States may provide for companies having a registered office on their territory to be only allowed to request the identification of shareholders holding more than a certain percentage of shares or voting rights. However, this percentage may not exceed $0.5 \%$.

${ }^{10}$ See the Commission Implementing Regulation (EU) 2018/1212 of 3 September 2018 laying down minimum requirements implementing the provisions of Directive 2007/36/EC of the European Parliament and of the Council as regards shareholder identification, the transmission of information and the facilitation of the exercise of shareholders rights [2018] OJ L223/1. Hereinafter: Implementing Regulation.
} 
Focusing on the European situation, this article provides an in-depth overview of the current (intermediated) shareholder engagement system and its related problems. In Sect. 2.1 we discuss the rationale of and the new provisions in the SRD II. We outline how shares of listed companies are currently held through chains of intermediaries in Sect. 2.2. Next, in Sect. 2.3 we explore the current shareholder identification framework. In Sect. 3, we discuss the different practices of and venues for shareholder engagement in practice to provide insights into the engagement behaviour of different types of shareholders. In Sect. 4, we propose the development of an effective facilitation system of shareholder rights using (permissioned) blockchain technology to solve the shareholder engagement problems outlined in Sects. 2 and 3. We also provide an overview of current blockchain initiatives in practice. Section 5 contains a conclusion and a discussion.

\section{The Current Intermediated System for Shareholder Voting and Engagement}

\subsection{The Shareholder Rights Directive II}

The EC noted that the first Shareholder Rights Directive (hereinafter: 'SRD') ${ }^{11}$ _ that already contained provisions regarding remote (electronic) voting, ${ }^{12}$ the disclosure of information prior to the general meeting, ${ }^{13}$ the publication of the voting results of the general meeting on the issuer's website, ${ }^{14}$ and the right of shareholders to ask questions ${ }^{15}$ - failed to bring the relationship between the shareholders and the issuer to its full maturity. Accordingly, on 9 April 2014, the EC announced a package to improve the corporate governance for listed companies, including the proposal to revise the SRD. ${ }^{16}$ In the Impact Assessment it was noted that all relevant

\footnotetext{
11 Directive 2007/36/EC of the European Parliament and of the Council on the exercise of certain rights of shareholders in listed companies [2007] OJ L157/87.

12 Art. 8 stipulates that Member States shall permit companies to offer to their shareholders any form of participation in the general meeting by electronic means, and lists three forms. Arts. 10 and 11 provide shareholders with the right to appoint a proxy holder to attend the AGM (or other general meeting), also by electronic means.

13 Art. 5 requires Member States to ensure that the convocation of the general meeting is issued at least 21 days before the meeting and outlines the minimum content. In addition to the SRD, Art. 17 of the Transparency Directive requires issuers to ensure that all the facilities and information necessary for shareholders to exercise their shareholder rights are available (Directive 2004/109/EC of the European Parliament and of the Council of 15 December 2004 on the harmonisation of transparency requirements in relation to information about issuers whose securities are admitted to trading on a regulated market and amending Directive 2001/34/EC [2004] OJ L390/38. Hereinafter: Transparency Directive).

14 Art. 14 requires the issuer to establish for each resolution the number of shares for which votes have been validly cast, the proportion of the share capital represented by those voters, the total number of votes validly cast, and the number of votes cast in favour, against and abstentions.

15 Art. 9(2) states that Member States may also allow companies to consider questions answered if the relevant information is available on the company's website in a question and answer format.

16 Proposal for a Directive of the European Parliament and of the Council amending Directive 2007/36/ EC as regards the encouragement of long-term shareholder engagement and Directive 2013/34/EU as regards certain elements of the corporate governance statement, COM(2014) 213 final, 9 April 2014.
} 
information was not always passed to shareholders, shareholders' votes became lost, and intermediaries were able to misuse shareholder voting rights. ${ }^{17}$

Preamble 4 of the SRD II reads that '[s] hares of listed companies are often held through complex chains of intermediaries which render the exercise of shareholder rights more difficult and may act as an obstacle to shareholder engagement'. It adds that ' $[\mathrm{t}] \mathrm{h}$ identification of shareholders is a prerequisite to direct communication between the shareholders and the company and therefore essential to facilitating the exercise of shareholder rights'. Accordingly, Article 3a of the SRD II includes rules for the identification of shareholders, including that, where there is more than one intermediary in a chain of intermediaries, the request of the company, or of a third party nominated by the company, is transmitted between intermediaries without delay (Article 3a(3)). Article 3a(1) indicates that Member States may provide for companies having a registered office on their territory to be only allowed to request the identification of shareholders holding more than a certain percentage of shares or voting rights. However, this percentage may not exceed $0.5 \%$. Article $3 a(4)$ states that companies should be able to identify shareholders in order to be able to communicate with them directly with the view to facilitating the exercise of shareholder rights and shareholder engagement.

Next, preamble 8 of the SRD II states that '[i]n the chain of intermediaries, especially when the chain involves many intermediaries, information is not always passed from the company to its shareholders and shareholders' votes are not always correctly transmitted to the company. The SRD II aims to improve the transmission of information along the chain of intermediaries to facilitate the exercise of shareholder rights.' Therefore, Article $3 \mathrm{~b}$ includes rules for the transmission of information from issuers to shareholders. In particular, paragraph 4 of this Article states that intermediaries need to transmit the information received from the shareholders related to the exercise of the rights flowing from their shares to the company without delay, and in accordance with the instructions received from the shareholders.

Preamble 10 adds that it is key for shareholders to know that their votes have been correctly taken into account and therefore confirmation of the receipt of votes should be provided in the case of electronic voting. Also, each shareholder who casts a vote should have the possibility to verify whether the vote has been validly recorded and counted. Article $3 \mathrm{c}$ concerns the facilitation of the exercise of shareholder rights by intermediaries, including the right to participate and to vote in general meetings. Article $3 c(2)$ states that when votes are cast electronically, Member States need to ensure that an electronic confirmation of the receipt of the votes is sent to the person that casts the vote. The second paragraph of Article 3c(2) holds that Member States need to ensure that shareholders or a third party can receive a confirmation that their votes have been validly recorded and counted by the company.

\footnotetext{
17 Impact Assessment Accompanying the document Proposal for a Directive of the European Parliament and of the Council on amending Directive 2007/36/EC as regards the encouragement of long-term shareholder engagement and Directive 2013/34/EU as regards certain elements of the corporate governance statement and Commission Recommendation on the quality of corporate governance reporting ("comply or explain'), SWD(2014) 127 final, 9 April 2014.
} 
On 4 September 2018, the Implementing Regulation laying down the minimum requirements for shareholder identification, the transmission of information, and the facilitation of the exercise of shareholder rights as determined in the SRD II was published. Preamble 6 of the Implementing Regulation states that not only the minimum requirements with respect to the transmission of information need to be established, but that ' $[\mathrm{t}]$ he aim is also to facilitate the handling of electronic voting instructions from shareholders to the issuer'. To facilitate the exercise of shareholder rights, intermediaries have the obligation 'to confirm the entitlement of the shareholders to participate in a general meeting, and the obligation to transmit the notice of participation to the issuer' (preamble 8). The EC recognizes that there are currently different ways to communicate the confirmation of shareholder entitlement to participation and that there is a need to standardise (preamble 9). Lastly, preamble 9 also adds that the Implementing Regulation lays down 'minimum types of information to be included in confirmations or receipt of votes and the recording and counting of votes'. Article 7 and Tables 6 and 7 of the Annex of this Implementing Regulation contain these minimum types of information that the confirmation of the receipt, recording and counting of votes need to comprise. ${ }^{18}$ Article 9(5) states that the voting receipt shall be provided to the shareholders immediately after the votes have been cast. The confirmation of the recording and calculation of votes in the general meeting shall be provided by the issuer in a timely manner and no later than 15 days after the general meeting. ${ }^{19}$

As we will see in Sect. 4, blockchain technology seems to meet the requirements outlined in the Implementing Regulation. However, before outlining the solutions that (permissioned) blockchain technology can offer, we first provide a more indepth analysis of the intermediated shareholder engagement system and the identification rules of shareholders (Sect. 2) and shareholder engagement practices (Sect. 3).

\subsection{The Current System of Intermediated Securities}

The complex procedure and process of the exercise of shareholder rights and shareholder engagement is largely a consequence of the growth and internationalization of the financial markets. Originally, when securities were traded, the paper stock

\footnotetext{
18 These include (Table 6 on the voting receipt): (i) a unique identifier of the receipt; (ii) the type of message; (iii) an unique identifier of the general meeting event; (iv) ISIN (international securities identification number); (v) the date of the general meeting; (vi) the name of the confirming party; (vii) the name of the shareholder, and (viii) a preproduction of the votes received. In Table 7 on the recording and counting of votes elements 1-5 and 7 are the same; the name of the issuer (vi), and the confirmation of the votes recorded and calculated (viii) are added.

19 It adds that ' $[\mathrm{w}]$ hen the intermediary receives such confirmation, it shall transmit it to the shareholder or third party nominated by the shareholder without delay and on the same business day as the receipt of the confirmation. Where there is more than one intermediary in the chain of intermediaries, the confirmation shall be transmitted between intermediaries without delay and on the same business day, unless the confirmation can be directly transmitted to the shareholder or third party nominated by the shareholder.'
} 
was delivered by hand, ${ }^{20}$ but the increased trading volume made it impossible to receive and deliver the securities in time; the involvement of intermediaries started. While trading still takes place at the stock exchanges, the (international) CSDs now hold the securities that are immobilized for investors. In theory, the investors maintain an account with the CSD and trading takes places through a debit-and-credit entry, usually in an electronic form. However, in practice, investors do not directly hold an account with the CSD, but hold accounts with their banks or brokers. These financial intermediaries in turn directly hold an account with the CSD or indirectly via other intermediaries. We summarize this system in Fig. 1.

Figure 1 displays a simplified share transaction process showing that the intermediaries and the CSD do not only play a role in the transfer of a security between a buyer and a seller as the central point for depositing securities, but also in the relationship between the investor (in Fig. 1 denoted in the combined position as the 'Buyer' of the shares in the secondary market) and the issuer.

Progressive growth and internationalization led to the establishment of other intermediaries between (international) investors and the CSD made the chain between the investor and the issuer even longer (the squiggly line in Fig. 1). This process initiated the emergence of many different systems for the registration of the (transfer of the) ownership of the shares without a uniform (legal) approach. More specifically, Unidroit's Guide on Intermediated Securities distinguished five different securities models ${ }^{21}$ : (i) the individual ownership model; (ii) the co-ownership model; (iii) the trust model; (iv) the security entitlement model; and (v) the contractual model. Whereas for instance in France, the individual ownership model in which the investor has full, individual ownership of the securities, is used, in Germany the co-ownership model in which the issuer deposits a global certificate with the CSD is used. In the former model, it is often not the investor but one of the intermediaries or the CSD that is registered as a shareholder of the company. In the German co-ownership model, the investor retains fractional ownership, corresponding to its holdings of a pool of securities held by the CSD. The English model is still different, as here they make use of the 'trust model' as seen in the DNick case, in which the CSD acts as the issuer's register and the intermediaries are considered to be the legal owners of the securities and act as trustees for the account holders, the investors and consequently the beneficiaries. In the security entitlement model, which is the model that is used in the US, the investor has a security entitlement against her intermediary who has an obligation to obtain and pass on the rights attached to the securities ${ }^{22}$; therefore, in this model the investor has no direct rights

\footnotetext{
${ }^{20}$ For a short and comprehensive overview of the problems of paper securities trading see FINRA (2015).

21 Unidroit (2009). In the European Union the system of central securities depositories is harmonized and governed by Regulation (EU) No. 909/2014 of the European Parliament and of the Council of 23 July 2014 on improving securities settlement in the European Union and on central securities depositories and amending Directives 98/26/EC and 2014/65/EU and Regulation (EU) No. 236/2012 [2012] OJ L 257/1.

${ }^{22}$ See for a recent, straightforward analysis of the complexities of the system and the voting process in the US, Geis (2018).
} 
against the issuer. Finally, in the contractual model, the investor acquires a bundle of contractual rights vis-à-vis the relevant intermediary.

Whether the CSD is familiar with the identity of the investor depends on the transparency of the system: the investor can be directly identified in the account system of the CSD or indirectly through a regular update of the (omnibus) account of an intermediary. Not all systems are equally transparent, and in some systems the investor is not legally considered to be the shareholder. In addition, when the issuer and the investor are located in different countries it is more than likely that more than one system is applicable to the relationship between the issuer and the investor. $^{23}$

\subsection{Current Shareholder Identification Framework}

In the last few decades, in addition to classical shareholder registers that are commonly held by companies, several ledgers with information related to the ownership of shares have been established. First of all, in the late 1980s, the EC aimed at enhancing both investor protection and investor confidence in the market ${ }^{24}$ with the Major Shareholding Directive. ${ }^{25}$ The shareholder must notify the issuer, within four trading days, of an acquisition or disposal of shares to which voting rights are attached as well as financial instruments to which a right to unconditionally acquire shares with voting rights are attached and exceeding or falling below the thresholds of $5,10,15,20,25,30,50$ and $75 \%$ of all shares. The notification must contain information regarding the identity of the shareholder and its chain of controlled undertakings, the number of voting rights immediately after the disposal or acquisition, as well as the date on which the transaction has taken place. The issuer must disclose all the information contained in the notification to the public within three trading days thereafter. ${ }^{26}$ Although the SRD II goes a big step further, requiring that more detailed ownership shall be exchanged with a minimum threshold of $0.5 \%$ of the shares or voting rights at a maximum (cf. supra, Sect. 2.1), practice shows that it is already possible to identify all shareholders in some cases. For instance, Euroclear Sweden seems to hold the official register of ownership of all Swedish listed companies. $^{27}$

\footnotetext{
${ }^{23}$ See for an analysis Aparicio (2017).

${ }^{24}$ Proposal for a Council Directive on information to be published when major holdings in the capital of a listed company are acquired or disposed of, $\operatorname{COM}(85) 791$ final, [1985] OJ C 351/35.

${ }^{25}$ Council Directive 88/627/EEC on the Information to be Published when a Major Holding in a Listed Company is Acquired or Disposed Of [1988] OJ L348/62. Currently this Directive is integrated in Section I of Chapter III of the Transparency Directive.

${ }^{26}$ In addition, the issuer must ensure that it is also making public any change in the rights attaching to the various classes of shares, including changes in the rights attaching to derivative securities issued by the issuer itself and giving access to the shares of that issuer, allowing shareholders to calculate their positions.

${ }^{27}$ Euroclear Sweden was able to identify 2.1 million shareholders, among which were 1.8 million Swedish individuals (Euroclear Sweden 2018, p 10).
} 


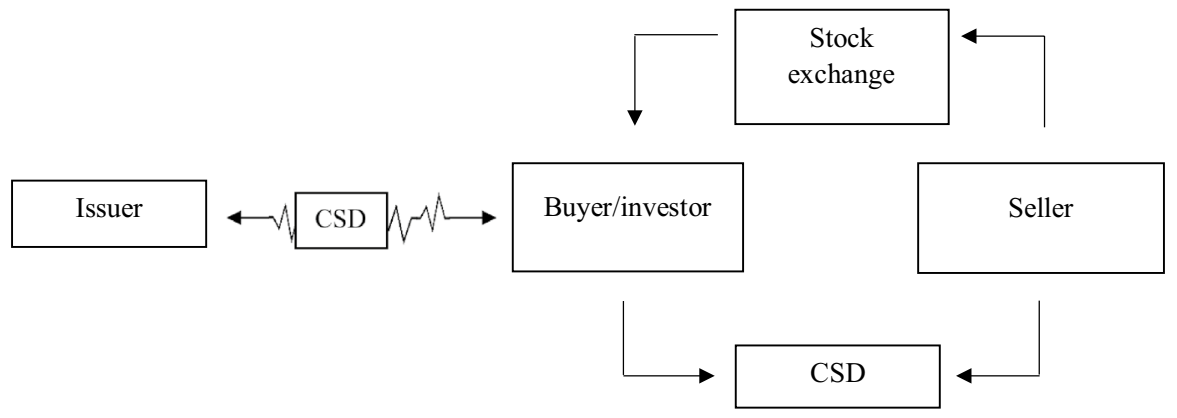

Fig. 1 The system of intermediated securities

Second, in 2003, the establishment and maintenance of another database related to ownership became mandatory. The EC wanted to reduce the probability of market abuse with the disclosure of the transactions of those persons charged with managerial responsibilities in companies and their associated persons. ${ }^{28}$ These persons also include senior managers who have regular access to inside information relating directly or indirectly to the issuer and who have the power to take managerial decisions affecting future developments and business prospects. ${ }^{29}$ Furthermore, also persons closely associated with the persons charged with managerial responsibilities are submitted to the disclosure requirements. ${ }^{30}$ These persons and their associates must notify the competent authority of the transactions conducted on their own account relating to shares or to derivatives or other financial instruments linked to them. Member States shall ensure that public access to information concerning such transactions, on at least an individual basis, is readily available as soon as possible. The notifications must be executed with the use of electronic means. ${ }^{31}$ For both notifications, i.e., those to be done by the insider and her relatives as well as those that the issuer must make public, three business days after the transaction has taken place are provided. ${ }^{32}$

Third, in the aftermath of the financial crisis, the European Union considered that short selling could threaten the viability of issuers, in particular financial institutions,

\footnotetext{
28 Art. 19 Regulation (EU) No. 596/2014 of the European Parliament and of the Council of 16 April 2014 on market abuse (market abuse regulation) and repealing Directive 2003/6/EC of the European Parliament and of the Council and Commission Directives 2003/124/EC, 2003/125/EC and 2004/72/EC [2014] OJ L173/1. Hereinafter: Market Abuse Regulation.

29 Art. 3(1)(25) of the Market Abuse Regulation.

${ }^{30}$ It includes spouses, children, relatives of the same household as well as legal entities, trusts and partnerships that the person discharged with managerial responsibilities controls.

31 Art. 2 of Commission Implementing Regulation (EU) 2016/523 of 10 March 2016 laying down implementing technical standards with regard to the format and template for notification and public disclosure of managers' transactions in accordance with Regulation (EU) No. 596/2014 of the European Parliament and of the Council [2016] OJ L88/19.

32 The regulation allows the competent authority to disclose the transactions instead of the issuer.
} 
and create systemic risk. ${ }^{33}$ The European Union therefore opted for increased transparency in the financial markets. A natural or legal person who has a net short position in relation to the issued share capital of an issuer must notify the supervisory agency before $15.30 \mathrm{~h}$ of the following trading day where the position, as calculated at midnight following the trading day, reaches or falls below a relevant notification threshold of $0.2 \%$ of the issued share capital and every $0.1 \%$ higher. ${ }^{34}$ Similarly, net short positions of $0.5 \%$ of the issued share capital and every $0.1 \%$ higher must be disclosed to the public. ${ }^{35}$ In the case of notification to the supervisory agency, confidentiality must be ensured. In the case of notification to the public, rapid access on a non-discriminatory basis must be ensured. ${ }^{36}$ Furthermore, the natural or legal person shall keep, for a period of 5 years, records of the gross positions which make a significant net short position.

Shareholders and investors have to provide information for all three aforementioned ledgers, ${ }^{37}$ but this current disclosure system is not waterproof. For example, note that the process of updating the database takes up to seven trading days when there is a notification of major holdings. In addition, there exist other types of transactions with shares which do not mandatorily have to be disclosed but can affect the voting rights position of shareholders. Stock lending is an example. In their seminal work, $\mathrm{Hu}$ and Black offered examples of lending shares before the record date influencing the voting outcome and affecting the stock price development (to the advantage of the share lender). ${ }^{38}$ They assessed that up to $20 \%$ of the shares can be borrowed, sufficient to take the reins at some general meetings of shareholders. ${ }^{39}$ Accordingly, the European Securities and Markets Authority ESMA recommends undertakings for collective investment in transferable securities (UCITS) to report

\footnotetext{
33 Recital (1) Regulation (EU) No. 236/2012 of the European Parliament and of the Council of 14 March 2012 on short selling and certain aspects of credit default swaps [2012] OJ L86/1.

34 Art. 5 of Regulation (EU) No. 236/2012.

35 Art. 6 of Regulation (EU) No. 236/2012.

36 The format of the notification can be found in Commission delegated Regulation (EU) No. 826/2012 of 29 June 2012 supplementing Regulation (EU) No. 236/2012 of the European Parliament and of the Council with regard to regulatory technical standards on notification and disclosure requirements with regard to net short positions, the details of the information to be provided to the European Securities and Markets Authority in relation to net short positions and the method for calculating turnover to determine exempted shares [2012] OJ L251/1.

37 In addition, there are also some specific requirements for identifying shareholder positions. For example, in their annual reports, undertakings for collective investment in transferable securities (UCITS) need to disclose their portfolio of transferable securities. See Schedule B of Directive 2009/65/EC of the European Parliament and of the Council of 13 July 2009 on the coordination of laws, regulations and administrative provisions relating to undertakings for collective investment in transferable securities (UCITS) [2009] OJ L302/32.

${ }^{38} \mathrm{Hu}$ and Black (2006), pp 1028-1029. The recent accusations of empty voting in the case of Premier Food Plc's 2018 AGM show that share lending is still a practice that needs to be taken into account. See Burgess (2018).

39 Previous studies have shown that shareholder voting turnout in shareholder meetings can be low, especially in continental European countries. See Lafarre (2017).
} 
on the applied efficient portfolio management techniques to generate additional income which includes stock exchange lending. ${ }^{40}$

\section{Different Practices of and Venues for Shareholder Engagement}

There are currently many venues of contact between issuers and their board of directors and the shareholders. First, there are AGMs and extraordinary general meetings of shareholders, which are especially important to small and individual shareholders. ${ }^{41}$ These meetings are accompanied by secondary information flows like written questions and answers, which are often made publicly available on the website of the company (cf. supra, Sect. 2.1). Second, many companies regularly organize webcasts, webinars, conferences and other (private) meetings with shareholders, financial analysts and investors. In addition to these meetings and roadshows, in several countries one can find online shareholder communication platforms, either voluntary at the company level like the shareholder clubs in France, or at the national level with a basis in statutory law, like the 'Aktionärsforum' in Germany (section 127a Aktiengesetz, 'AktG').

\subsection{Exercising Shareholder Voting in Practice}

AGMs and other general shareholder meetings are the primary place for shareholder engagement. While shareholders previously voted in person at the meeting or were represented by other persons to exercise all of their rights, this is no longer common. Many shareholders cast their vote electronically, sometimes long in advance of the meeting. ${ }^{42}$ Others authorize the chairman of the general meeting of shareholders to vote. As the convocation of the general meeting is published at least 3 weeks before the day of the meeting, electronic voting and providing proxies to the chairman starts shortly thereafter.

We find that electronic voting tools and providing a proxy to the chairman are used by many shareholders, often representing more than half of the total voting rights. Eleven companies ${ }^{43}$ of the CAC-40 regularly disclose detailed voting records of four different voting mechanisms: attending in person, shareholders represented at the meeting, proxies given to the chairman and postal (electronic) votes. Figure 2 summarizes the findings. ${ }^{44}$

\footnotetext{
40 Guideline 35 of ESMA (2014).

41 See, for instance, Lafarre (2017).

42 The UK Companies Code 2006 explicitly provides that the document for casting a vote cannot be required to be received by the company more than 48 hours before the time for holding the meeting (section 322A).

43 These companies are: Atos, Accor, BNP, Michelin, Orange, Pernod-Ricard, Safran, Sanofi, Schneider, Unibail-Rodamco, Veolia.

44 For 2018 only 9 companies are included. The AGM of Pernod-Ricard took place in November 2018, while the detailed minutes of the meeting of Unibail-Rodamco, which contained information on the different voting mechanisms that shareholders had made use of, were not yet available on 1 June 2018 (it should be noted that the results of the meeting had already been disclosed).
} 
Figure 2 shows that only a small share of the participating shareholders (in terms of voting rights) are present in person; while close to one third of all attending shares with voting rights belonged to shareholders attending the meetings of 2012 in person, this number gradually decreased to less than $20 \%$ in $2018 .{ }^{45}$ A vast majority of shareholders empower the chairman of the meeting to vote, while only a very small number give a proxy to another person attending the meeting. Between 40 and $50 \%$ of the total number of shareholders participating in the voting have the chairman as a representative, another $0.4 \%$ up to $3.8 \%$ of the shareholders were represented by a third party (not displayed in Fig. 2). However, these shareholders have only very small voting blocks in the company, as demonstrated in Fig. 2; the total votes of the shareholders that provided a proxy to the chairman decreased from 3.6 in 2012 to $3 \%$ in 2018 and the voting rights of the persons representing non-attending shareholders varied from $0.12 \%$ to a maximum of $1.35 \%$. Consequently, a very large bulk of the votes were sent in by mail. The aggregate voting stakes of shareholders participating through sending in their votes by (electronic) mail soared from $63 \%$ in 2012 to over $77 \%$ in $2018 .{ }^{46}$ Approximately $40 \%$ of the shareholders make use of this voting mechanism (not displayed in Fig. 2), signaling that in particular larger, most likely institutional, shareholders benefit from this instrument. To conclude, the data show that an overwhelming majority of the shareholders, representing a large majority of the voting rights, are not using the AGM as a platform to engage in discussions with the board of directors.

The practice of remote voting can cause several problems, in addition to the problems caused by the chains of intermediaries as outlined before. First of all, a direct consequence of using remote voting is that the voting information becomes available to some before the meeting takes place; as a large majority of the shareholders make use of voting by mail, the recipient of the votes is already familiar with how the shareholders have expressed their voice. Hence, as nowadays even around $80 \%$ of the votes are voted via this tool, the final results of the agenda items of the AGM may already be known to an intermediary or the issuer itself, even before the AGM takes place, thereby creating information asymmetries and impediments to the importance of the physical AGM.

Secondly, the recent takeover of GKN Plc by Melrose Industries Plc shows that voting items can be substantially changed during the course of the AGM. The AGM of GKN was held on 3 May 2018, and on 3 April 2018 the meeting notice was issued. Resolutions 3-10 concerned the (re-)election of its directors. ${ }^{47}$ However, on 19 April 2018 a majority of the GKN's board stepped down as a result of the offer by Melrose Industries and Melrose's directors replaced them on the board.

\footnotetext{
45 In companies in which the French government is a significant shareholder, the attendance of shareholders in person is higher. This is particularly the case for Orange and Safran where over 40 per cent of the votes belong to shareholders attending in person, and even 60 percent at Safran's 2012 meeting.

46 And even more than 95\% at Atos (Van der Elst and Lafarre 2017, p 171).

47 See GKN Plc's 2018 AGM notice, GKN Plc (2018a). The names of the directors who were up for re-election were: M.J. Turner, A. Stevens, P.A. Swash, A.G. Cockburn, T. Erginbilgic, S.C.R. JemmettPage, and R. Parry-Jones. These directors were all incumbent directors of GKN Plc as its 2017 annual report indicates.
} 


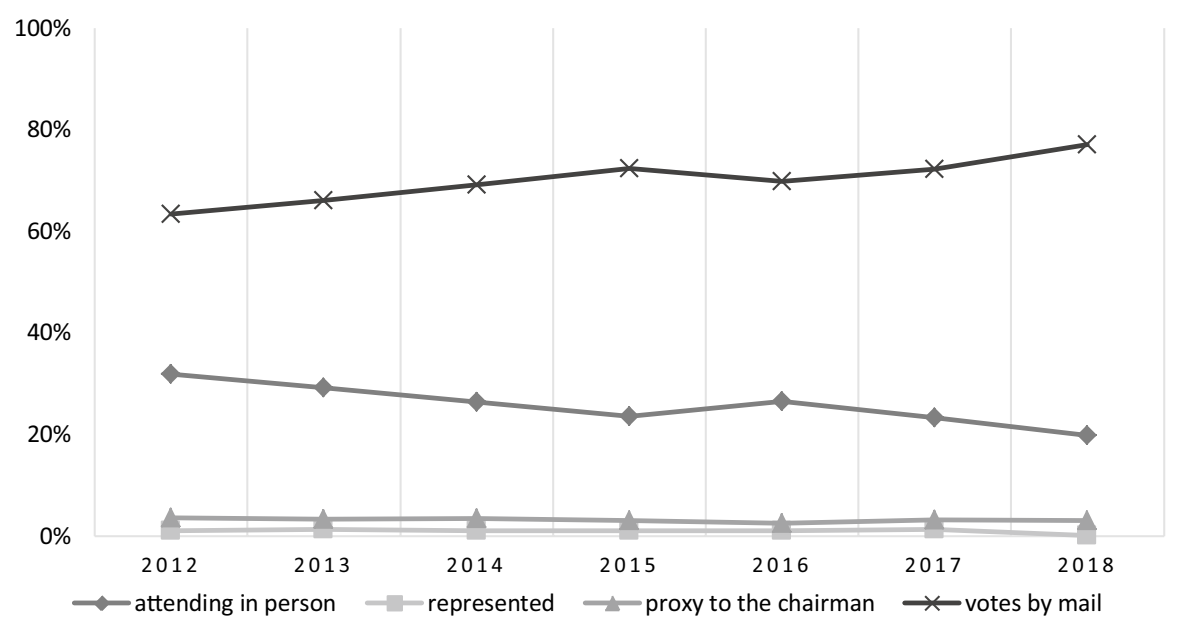

Fig. 2 Different voting methods in French companies (\% voting rights)

Therefore, the voting items concerning the re-election of the GKN directors were amended during the 2018 AGM, now containing the election of Melrose's nominees. ${ }^{48}$ This raises important questions, as only shareholders who attended the meeting in person were able to know the amendments to the resolutions. Manifest indicates that 'it appears, from the meeting results, that proxies may have been applied to the amended resolutions' ${ }^{49}$ This conclusion can be deduced from the total number of votes; the amended resolutions received votes of over $92 \%$ of the share capital, similar to other resolutions that were put to a vote during this AGM. Hence, it seems to be the case that many shareholders of GKN plc who used the remote voting tool cast their votes for one director, but de facto 'elected' another director.

\subsection{Institutional Investor Engagement and Voting Policies}

Regulators nowadays place great emphasis on the stewardship role of institutional investors in large corporations to stimulate long-term value creation. For instance, principle 1 of the UK Stewardship Code 2012 states that institutional investors should publicly disclose their policy on how they will discharge their stewardship responsibilities. Principle 6 adds that institutional investors should have a clear policy on voting and the disclosure of voting activity. They should seek to vote all shares held and not automatically support the board. Also the SRD II pays special attention to institutional investors and obliges Member States to ensure that

\footnotetext{
48 Resolutions 3-8 in the voting results include the election of directors: C. Miller, D. Roper, S. Peckham, E. Martin, J. Crawford, and G. Barnes. Resolutions 9-10, containing the re-election of S. JemmettPage and R. Parry-Jones, were withdrawn with the notification that 'Shonaid Jemmett-Page and Richard Parry-Jones each resigned as a Director of the Company on 19 April 2018 and the resolution to re-elect them are therefore redundant'. See GKN Plc's 2018 AGM voting results, GKN Plc (2018b).

49 See Manifest (2018).
} 
institutional investors comply with the requirements to develop and publicly disclose a shareholder engagement policy and to disclose, on an annual basis, how this engagement policy has been implemented (Article 3g). If institutional investors do not comply, they have to disclose a clear and reasoned explanation.

We consider how institutional investors exercise their stewardship responsibilities in practice. It is often stated that institutional investors, and other larger shareholders, have the opportunity to engage with corporate boards and company representatives during private meetings outside the AGMs. ${ }^{50}$ In an interview with the Wallstreet Journal, three large institutional investors stated that they 'like to work behind the scenes and talk with their portfolio companies routinely about their policies and plans'. ${ }^{51}$ BlackRock indicates that they have basic, moderate and extensive engagements, varying from one conversation on a routine matter to numerous meetings over a longer timeframe. Vanguard and State Street state that each phone call or meeting counts as an 'engagement'. 52

We further examine the engagement policies of these three large institutional investors. In its Investment Stewardship guideline of October 2017, when explaining its 'Vote execution', BlackRock emphasises voting proxies and it does not mention anything about physically attending meetings or posing questions to corporate boards. However, it seems to have private 'engagement meetings' with executives and board directors, as well as with the company's advisors. ${ }^{53}$ Vanguard Asset Management states that '[ $t$ ] he most visible sign of Vanguard's engaged ownership is our funds' proxy voting at shareholder meetings' ${ }^{54}$ In addition, in its 2017 annual report, Vanguard indicates that it engages 'with portfolio company executives and directors to share [their] corporate governance principles and learn about portfolio companies' corporate governance practices. ${ }^{55}$ This so-called 'quiet diplomacy' approach is pursued via private meetings with companies. ${ }^{56}$ State Street Global Advisors states that it maximizes 'its voting power and engagement by maintaining a centralized proxy voting [...]' and believes '[that] direct communication with executive board members and independent non-executive directors is critical [...]. Where appropriate, we [...] communicate with company representatives about common concerns.' 57

This brief analysis of the engagement practices of these three large institutional investors above seems to indicate that institutional investors indeed engage with

\footnotetext{
${ }^{50}$ For example, see Tiemstra and De Keijzer (2008); Van der Elst (2014).

51 Krouse (2018).

52 The article states that BlackRock had 1603 'engagements', Vanguard Group 954, and State Street Corporation 676.

53 See BlackRock (2017), p 6: 'In addition to meeting with executives and board directors, we may also communicate with the company's advisors, and engage with other shareholders where appropriate.'

54 Vanguard's investment stewardship policies and guidelines, https://about.vanguard.com/investment -stewardship/policies-and-guidelines/ (accessed 8 June 2018).

55 Vanguard (2017).

56 See Flood (2018).

57 State Street (2018), p 2.
} 
corporate boards and company representatives during private meetings outside $\mathrm{AGMs}^{58}$ and use the proxy voting tool for voting at AGMs. Whereas the AGM is the place were all shareholders, including small private investors, have the opportunity to ask questions and directly engage with the corporate board, to our knowledge, none of these three identified institutional investors being physically (re)present(ed) at AGMs ask questions. An empirical analysis of the Dutch AGM minutes of Lafarre and Van der Elst (2019) provides a further indication; although these institutional investors have stakes in a vast number of Dutch listed companies, ${ }^{59}$ none of the almost 30,000 questions that were raised in the sample of 763 Dutch AGMs of 69 major Dutch listed companies (large-cap and midcap) were from any of the three institutional investors. To conclude, it seems that there are different means for institutional investors (and other larger shareholders) than for small (private) shareholders to engage with companies. ${ }^{60}$

\section{Blockchain Technology for the Shareholder Community}

In the previous sections we have discussed several current problems related to the intermediated system of shareholder engagement. These problems can roughly be divided into two main categories: (i) the complex system of intermediaries in the exercise of shareholder rights and information flows, creating a lack of transparency, verification and trust between shareholders and issuers; and (ii) the different means for different types of shareholders to engage with companies, creating information problems and inequalities between different classes of shareholders. In addition we note that, especially in the case of shareholder identification rules, the current system makes use of scattered ledgers for (delayed) disclosure. In this section we strongly advocate the use of blockchain technology to solve these problems.

\footnotetext{
58 A recent article in the Financial Times also suggests that (institutional) shareholders are able to meet with the corporate board of BT Group Plc before the AGM takes place; whereas the 2018 AGM was to be held in July, several large shareholders 'called for meetings with BT chair Jan du Plessis to discuss Mr Patterson's future, voicing doubts over whether he is the right person to lead the business as it undergoes an ambitious restructuring'. See Mooney and Fildes (2018). Shortly afterwards and still long before the AGM, the CEO Patterson was sacked (Fildes et al. 2018).

59 Following the Substantial holdings and gross short positions register of the AFM (the Financial Markets Authority of the Netherlands), available at https://www.afm.nl/en/professionals/registers.

60 Another example of private meetings with particular shareholders is given in the letter of the chairman of the compensation committee of WPP, Annual Report WPP 2012, p 121: 'the chairman of the Company and I began a series of meetings with share owners and representative bodies to listen to their issues and concerns so that the committee could formulate proposals to address them. [...] [W] e have engaged with our largest share owners and the representative bodies numerous times.' See for other examples Van der Elst (2017).
} 


\subsection{Blockchain Technology}

Blockchain can be described as a(n) (open) distributed ledger that can store transactions between (unknown) parties in a verifiable and immutable way. ${ }^{61}$ In particular, whereas the classical ledgers are often held in a centralised manner, with blockchain technology everybody holds the ledger. New transactions are broadcast to the network and these transactions, together with the proof of work of the previous block, are the new proof of work, ${ }^{6}$ and a timestamp added to the blockchain in a new block, thus chaining all blocks together. This proof of work concept is the commonly used consensus protocol for public blockchains. ${ }^{63}$

The data of the transactions in a block are stored using 'Merkle trees'. Merkle trees are constructed bottom-up, where one can find individual transactions (i.e., the underlying data) and their hashes. From the pairs of these hashes new hashes are constructed, and this action is repeated until there is only one hash. This single hash that is situated at the top of the Merkle tree is also called the Merkle root. Since changing any transaction (including the order) will change the Merkle root, the transaction data can be verified and validated (and is therefore immutable). As the Ethereum White Paper puts it,

a node can download only the header of a block from one source [...] and still be assured that all of the data is correct. [I]f a malicious user attempts to swap in a fake transaction into the bottom of a Merkle tree, this change will cause a change in the node above, and then a change in the node above that, finally changing the root of the tree and therefore the hash of the block, causing the protocol to register it as a completely different block.

Hence, although blockchains are continuously growing records, the validation of the data only requires small parts of the information transmitted in the network.

Blockchains are often divided into 'public' and 'private' ones. Information can be stored in a public ledger ('unpermissioned') or a private one ('permissioned') and contains all transactions that are executed. Both blockchains are decentralized and each participant in the blockchain keeps a replica of the ledger; these replicas are synchronised via a consensus mechanism like the proof of work concept as discussed above. Although there are important similarities between these two types, the distinction between both is pivotal for the involvement of shareholders in corporate

\footnotetext{
61 Iansiti and Lakhani (2017).

62 With the proof of work concept, miners solve a complex problem, usually using the SHA 256 hash function. In particular, they have to find a solution so that the input (i.e., including the solution of the previous block, the transactions together with this solution) results in an output starting with a large amount of zeros using the SHA 256 hash function. This solution cannot be predicted nor inversely be computed and thus demands large computing power. For more information, see the Ethereum White Paper, https:// github.com/ethereum/wiki/wiki/White-Paper (accessed 8 June 2018).

63 Other consensus protocols are the proof of stake concept, in which instead of computational powers, the currency holdings play a role, or the delegate proof of stake concept as used by EOS. For more information on the proof of work concept, see the Ethereum White Paper. For the delegated proof of stake concept, see the EOS White Paper, https:/github.com/EOSIO/Documentation/blob/master/TechnicalW hitePaper.md. (accessed 16 July 2018).
} 
life; whereas the unpermissioned ledger allows anyone to participate, the permissioned ledger allows for a pre-selection of the participants based on the satisfaction of certain requirements or on approval by an administrator or 'permissioner'. In other words, these participants need to have 'permission' for their activities. Note that, in contrast to the unpermissioned blockchain, the permissioned blockchain is not completely decentralised in the sense that it still requires participants to meet certain requirements which have to be determined by, for instance, a centralized authority. ${ }^{64}$ On the other hand, while still capturing the advantages of the verifiable and immutable storage of data, private blockchains are not faced with high amounts of computing power required to run the network. ${ }^{65}$ As we will see in Sect. 4.3 where we explore the current blockchain use for shareholder involvement in practice, many of these initiatives use a permissioned blockchain.

When considering a permissioned blockchain, we are only a small step away from other distributed systems like Git. Git is a distributed version control system that tracks changes in computer files; there is no need for a server to receive the history of any project as this can simply be read from a local database. ${ }^{66}$ Just like blockchain technology, Git makes use of structures similar to Merkle trees and stores the hash value of the data. In that respect, Git is comparable to permissioned blockchains, sharing the characteristic of being a distributed ledger that can store transactions in a verifiable and immutable way. However, blockchain technology uses a consensus protocol and allows for smart contracts to automatically perform the obligations that the parties have committed themselves to under their agreement, which are essential in our shareholder engagement application. Nonetheless, Git may still be a useful distributed system for the modernization of (some aspects of) shareholder engagement.

\subsection{Shareholder Engagement with Blockchain Technology}

In the introduction and Sect. 2, we have seen that today's intermediated shareholder engagement systems suffer from their complexity, leading to problems like the DNick and T. Rowe Price cases demonstrate. As blockchain technology ensures that the data is stored on a distributed ledger in a verifiable and immutable way, at least in theory, there is no longer any need for an intermediary to establish trust between the issuer and shareholders. We suggest using a permissioned distributed ledger to constitute a set of rules for shareholder voting, including majority requirements and

\footnotetext{
64 An example of an unpermissioned blockchain is the Hyperledger Fabric blockchain of the Linux Foundation and IBM. For a permissioned blockchain, a CSD (or a stock exchange or another party) could act as a centralized authority providing access to and exit from the permissioned ledger. IBM indicates that, in addition to a centralized authority, also existing participants can be able to decide on future participants (which can for example be linked to the 'proof of stake consensus'), or a consortium could be involved in decision-making. However, one may note that this access control should initially be determined by the initiator of the network. See the IBM Blockchain Blog (2017).

${ }^{65}$ It should be noted that there are other solutions for the proof of work protocol, for instance one may refer to Tangle, https://www.iota.org/ (accessed 16 July 2018).

66 For more information, see https://git-scm.com/book/en/v2/Getting-Started-Git-Basics.
} 
access rights, so that shareholders can exercise their rights in accordance with the applicable corporate law framework and the company's articles of association. For instance, in Europe, only shareholders who meet certain national requirements can add their own proposal to the agenda (i.e., the shareholder agenda right as specified in Article 6 of the SRD). The consensus protocol reassures participants that the information in the distributed ledger is correct and can be relied upon. Moreover, shareholders will be able to verify that their vote is included in the voting outcome. ${ }^{67}$ The use of blockchain technology can significantly reduce the number of intermediaries, both in share trading and in the exercise of shareholder rights, thus integrating the system of intermediated securities.

Next, we have seen that different types of shareholders use different means to engage with companies. For instance, institutional investors and large shareholders have private meetings with companies in order to ask questions and to voice their ideas or concerns. In contrast, especially small private shareholders usually only have the opportunity to engage directly with the corporate board at the AGM or another general meeting. It is usually only during these meetings where formal decision-making takes place that these shareholders can ask their questions to the corporate board and start discussions. Blockchain technology can harmonize shareholder engagement opportunities by offering a common discussion platform for shareholders and board members. Such a platform will be digital, which has previously led to some shareholder rebellion in the US in the context of virtual meetings. ${ }^{68}$ Opponents of virtual meetings, including small shareholders, claim that board members may ignore their questions in AGMs, and that this is much harder to do at physical meetings. ${ }^{69}$ Note that blockchain technology may offer the required scope and appropriate platform for improvement: all questions from shareholders may be included in the blockchain, and thus become transparent, verifiable and immutable, and so do the (absent) answers of corporate boards. ${ }^{70}$ In this way, in contrast to what the opponents of virtual-only meetings suggest, blockchain technology may actually enhance the forum function of the AGM for shareholders. This offers an interesting avenue for further research on the merits and demerits of full virtuality. ${ }^{71}$ In addition

\footnotetext{
${ }^{67}$ Note that shareholders need to be able to see how their own vote is counted in the voting result, but not the voting decision and the identity of other shareholders. However, since institutional investors need to publicly disclose information about the implementation of their engagement policy and in particular how they have exercised their voting rights following the SRD II (cf. supra, Sect. 3.2), for these shareholders it may actually be beneficial that other shareholders can see their voting decision in the blockchain in a trustworthy and transparent way.

68 Note that in contrast to US state law, the law in many European countries does not allow for organizing an electronic AGM only. For example, the Belgian Companies Code requires the company to organize an AGM in the municipality provided in the articles of association (Art. 552 Belgian Companies Code). A similar provision can be found in the Dutch Civil Code (Book 2: 116 Dutch Civil Code).

69 See Mooney (2017); Fontenot (2017-2018).

70 For instance, it is common practice in Dutch AGMs to subsequently answer questions by email when there has been no time to provide an answer during the meeting itself. Moreover, shareholders are not limited to the traditional duration of the AGM, but can be enabled to ask questions during a longer period, for example from the record date onwards. Also see Lafarre and Van der Elst (2019).

71 Also see ICLEG (2016).
} 
to the benefits of further harmonizing engagement opportunities for different types of shareholders, the immutability characteristic of blockchain technology will also solve problems relating to amending resolutions during the AGM itself where shareholders that have remotely cast their votes are not present.

Ideally, the information on shareholder ownership stakes and identification is also stored in the blockchain, so that there is no need for intermediaries to inform the 'permissioner' in the permissioned blockchain to grant shareholders permission to vote in the shareholder meeting or to perform other actions depending on their voting stake. Also the issuer may directly be able to identify its shareholders as required in the SRD II. As the initiative of the Australian Securities Exchange (ASX) shows (cf. infra, Sect. 4.3.1), ${ }^{72}$ both clearing and settlement and the exercise of shareholder rights can be facilitated via blockchain technology, showing that this integration would be feasible. ${ }^{73}$

As we have seen in Sect. 2.1, the Implementing Regulation sets out the requirements for the implementation of the SRD II communication framework and stimulates the use of new technologies. It seems that blockchain technology can fulfil these requirements and purposes, including, inter alia, the transmission of information and the handling of electronic voting instructions from shareholders to the issuer (preamble 6 of the Implementing Regulation); uniform, automated and the smooth application of the issuer's right to know its shareholders (preamble 5); the standardisation of the confirmation of entitlement to participate in the AGM (preamble 9); the swift processing of transmissions and ensuring that information reaches shareholders cross-border (preamble 10); and the secure transmission of confidential data (preamble 12).

\subsection{Current Blockchain Initiatives for the Shareholder Community}

Although blockchain technology in corporate governance is still in an early, exploratory phase ${ }^{74}$ recent regulatory and practical initiatives have shown that blockchain technology in this area is definitely feasible. ${ }^{75}$ From 2015 onwards, several initiatives have been developed (including prototypes) related to the trading of securities, including shares in the blockchain and the exercise of shareholder rights. In this section we discuss and compare the (regulatory) initiatives. ${ }^{76}$

\footnotetext{
72 ASX (2018).

73 Nonetheless, we have to add that the current shareholder identification framework that contains scattered ledgers with sometimes long disclosure delays, as outlined in Sect. 2.3, can also be further harmonized using existing standards such as XBRL.

74 Yermack (2017).

75 In contrast to shareholder voting blockchain applications, there are numerous stock exchanges that are looking into blockchain technology for stock trading processes in order to reduce transaction costs in a secure manner, including for example Nasdaq, Australian Stock Exchange, Japan Exchange Group, Deutsche Börse, London Stock Exchange and Moscow Exchange. For an overview, see Bajpai (2017).

${ }^{76}$ However, it should be noted that most of these initiatives are announced via press releases. This research was conducted up until 10 June 2018.
} 


\subsubsection{Blockchain Shareholder Engagement Initiatives in Practice}

Blockchain technology can be of use for different applications in relation to shareholders, including the issuance of stock. For instance, Overstock.com, an American internet retailer, was among the first companies that issued preferred stock on a public ledger in December 2016 - the so-called ' $t \varnothing$ platform'. ${ }^{77}$ In Europe, we can point to the German Central Bank that, together with the Deutsche Börse, announced in November 2016 the development of a prototype for securities settlements. ${ }^{78}$ This initiative claims to use the Hyperledger Fabric of the Linux Foundation blockchain technology. ${ }^{79}$ However, the first stock exchange that is actually replacing its current clearing and settlement system ('CHESS') with blockchain technology is the Australian Securities Exchange ASX in collaboration with Digital Assets Holdings. ${ }^{80}$ In its Consultation Paper of April 2018, ASX indicates that it 'will replace CHESS with a post-trade solution that provides users with more efficient clearing, settlement and other post-trade services [...]'. ${ }^{81}$ This 'post-trade solution' incorporates a permissioned distributed ledger. In addition to clearing and settlement, the Consultation Paper demonstrates other features of the blockchain technology, inter alia, providing proxy voting 'for all relevant issuer meetings', thereby indicating that 'the record date relative to the meeting date will be standardised so that the record date will be a fixed number of business days prior to the meeting date'. In addition, ASX states that electronic proxy voting via blockchain technology 'has the potential to involve the underlying beneficiaries in the proxy voting process.

ASX is not the only party that has announced electronic proxy voting using blockchain technology. To our knowledge, Deutsche Börse Group was among the first to develop a prototype, which was presented during its 'Open Day 2015' IT Conference. ${ }^{82}$ After Deutsche Börse, Nasdaq, in collaboration with the Estonian government, was the first to actually use the corporate voting blockchain application in practice. In February 2016, Nasdaq announced a blockchain based e-voting application that allows shareholders who hold shares in companies listed on the Tallinn Stock Exchange to vote remotely in AGMs. ${ }^{83}$

Besides Nasdaq, other parties also started to use blockchain technology for shareholder proxy voting in 2016. The ADX (Abu Dhabi Securities Exchange) started exploring blockchain technology for shareholder voting in 2016 and in the spring of 2017 it announced that the blockchain technology was used to organize the shareholder e-voting in the AGMs of six listed companies. ${ }^{84}$ In addition, also the Russian CSD, the National Settlement Depository (NSD), announced in 2016 that it had tested an e-proxy voting system prototype using Linux Foundation's Hyperledger

\footnotetext{
77 See Overstock.com (2016).

78 Deutsche Bundesbank (2016).

79 For more information, see www.hyperledger.org. Cf. supra, Sect. 4.1.

80 Smyth (2017).

81 ASX (2018).

82 See Deutsche Börse (2015). It states that 'non-bitcoin blockhain' software was used.

83 Nasdaq (2016).

84 See Finextra (2017).
} 
Fabric platform. ${ }^{85}$ Another initiative that uses the Hyperledger permissioned blockchain technology, that was recently announced in the media, is the collaboration between the Central Securities Depository of Poland and IBM to use blockchain technology for shareholder voting in AGMs. ${ }^{86}$

Other initiatives that were launched in 2017 include the cooperation between TMX Group and Accenture Plc, ${ }^{87}$ and the cooperation between Broadridge, J.P. Morgan, Banco Santander Investment, and Northern Trust. In May 2018 it was announced that Broadridge had been granted a US patent for shareholder proxy voting using permissioned blockchain technology ${ }^{88}$ The description of the invention in the patent is extensive and mentions, inter alia, an 'Ethereum-like environment' and the Hyperledger Fabric. ${ }^{89}$ In addition, on 17 May 2018 it was announced that one of the partners of Broadridge, Banco Santander, had 'scored a digital coup' using a permissioned blockchain-based shadow register for their 2018 AGM. $^{90}$ In the Netherlands, the custodian bank KAS Bank was the first to run a permissioned blockchain-based shareholder proxy voting pilot scheme during their 2018 AGM in April. ${ }^{91}$ Other recent initiatives include a collaboration between Strate and Nasdaq on remote shareholder voting in South Africa, ${ }^{92}$ and the "successful scaled pilot" AST Financial and the blockchain firm NuArca.

\subsubsection{Legislative Initiatives}

Also legislators have shown their interests in using blockchain technology. In Arizona, Nevada, Vermont and Delaware different legislative amendments have been introduced to facilitate the use of blockchain ${ }^{94}$; in Arizona, signatures, records and

\footnotetext{
85 See NSD (2016).

86 IBM (2017).

87 See Ho (2017).

${ }^{88}$ Broadridge filed the application on 9 November 2017. The patent also includes repurchase agreements. See http://patents.com/us-9967238.html.
}

${ }^{89}$ In its patent, Broadridge claims 'a computer system, comprising a network of externally owned presence (EOP) member nodes [...] and a plurality of self-contained self-executing software containers (SESCs) [...] wherein the plurality of SESCs comprises a plurality of meeting SESCs' (claims 1 and 2 and claims 7 et seq.). These so-called SESCs are configured to obtain the current data related to an AGM, comprising the 'agenda data, ballot data, entitlement data, and voting data' (claims 4 and 10). Patent claims 5 and 12 contain the access criteria for the permissioned blockchain, stating that verification is needed so that i) a particular investor can access only a vote entitlement related to the particular investor; ii) a particular custodian can access only the vote entitlement when the particular investor is a client of the particular custodian; and iii) a particular issuer can access only vote details without accessing related investor data.

90 See Mooney and Megaw (2018).

91 For more information, see KAS Bank (2018).

92 Nasdaq (2017).

93 AST Financial (2017).

94 The research is up to date until 31 May 2018. Note that, for example, in Illinois a bill for blockchain technology is pending (HB5553, filed 16 February 2018) and New Jersey has established a Block Chain Initiative Task Force to study whether it would be beneficial to transit to a blockchain-based system of recordkeeping and service delivery (New Jersey Assembly Bill 3613, 12 March 2018). The Colorado Senate Bill 18-086 (7 February 2018) aims to reduce the risk of identity theft with blockchain tech- 
(smart) contracts secured through blockchain technology cannot be denied legal effect, ${ }^{95}$ and Vermont allows use to be made of facts and records stored in the blockchain in a court trial. ${ }^{96}$ In Nevada, the state forbids local communities from imposing any taxes on the use of a blockchain or from imposing any permit or licence for making use of a blockchain. ${ }^{97}$ Delaware amended its DGCL and introduced the use of blockchain technology on 21 July 2017. The law facilitates the use of distributed ledgers for creating and maintaining corporate records (section 224 DGCL): '[a]ny records administered by or on behalf of the corporation in the regular course of its business, including its stock ledger, books of account, and minute books, may be kept on, or by means of, or be in the form of, any information storage device, method, or 1 or more electronic networks or databases (including 1 or more distributed electronic networks or databases) [...].' Transitioning to a distributed ledger can take place immediately for newly established companies but for existing companies some hurdles need to be overcome. ${ }^{98}$

In France, Article 120 of the Loi Sapin II empowered the government to introduce distributed ledger technology for trading securities: "[ $t$ ]he government is authorized to [...] amend the law applicable to financial securities in order to allow the proof and transmission, by means of a distributed ledger technology, of financial securities which are not admitted in a central securities depository that operate securities settlement systems nor admitted for the delivery of securities in such a central securities depository system,. ${ }^{99}$ The European CSD regulation ${ }^{100}$ prevents the French government from expanding the distributed ledger technology to securities admitted to a stock exchange. In an executive instrument of 8 December 2017 it is provided that the distributed ledger can be used for the registration of securities, for the registration of the assignment and for the identification of the ownership of the securities. ${ }^{101}$ A decree issued by the French Council of State must specify the conditions for pledging the securities into a blockchain. ${ }^{102}$

Footnote 94 (continued)

niques. In Wyoming a bill is pending to consider that a developer or seller of an open blockchain token is not as an issuer of a security (HB 70, 24 January 2018).

95 ARIZ. REV. STAT. ANN. § 44-7061 (2017).

9612 V.S.A. $\$ 1913$ (2017).

97 NEV. REV. STAT. ANN. SB 398, § 4 (2017).

98 Some authors have already argued that a successful use of a blockchain for trading in existing shares will depend on the willingness of a substantial number of incumbent parties to switch to the new system. See Geis (2018), pp 6-7; Song (2017), p 19.

99 Authors' own translation. Loi $n^{\circ} 2016-1691$ du 9 décembre 2016 relative à la transparence, à la lutte contre la corruption et à la modernisation de la vie économique, French Official Journal no. 287, 10 December 2016.

100 Regulation (EU) No. 909/2014 of the European Parliament and of the Council of 23 July 2014 on improving securities settlement in the European Union and on central securities depositories and amending Directives 98/26/EC and 2014/65/EU and Regulation (EU) No. 236/2012 [2014] OJ L257/1.

101 Ordonnance $n^{\circ} 2017-1674 d u \quad 8$ décembre 2017 relative à l'utilisation d'un dispositif d'enregistrement électronique partagé pour la représentation et la transmission de titres financiers, French Official Journal no. 287, 9 December 2017.

102 The executive instrument instructed the Council of State to issue the decree before 1 July 2018. The French Council of Ministers approved a bill to ratify ordonnance no. 2017-1674 of 8 December 2017 on 
Both the US and French legislative initiatives show the willingness of the government to provide a modern institutional framework and to shift some parts of business life and securities trading to an advanced digital platform.

\section{Conclusion and Discussion}

Despite living in a digital age with 'state of the art' technologies being available, current securities trading systems and shareholder engagement systems are faced with large-scale classical inefficiencies. The long chains of intermediaries in the exercise of shareholder rights and the transmission of information between shareholders and the issuer are sub-optimal, not only in terms of adding extra transaction costs with all these intermediaries an sich, but they are also causing problems as shareholder votes and other information are not always correctly transmitted. Moreover, the current shareholder engagement system triggers different types of shareholders to engage with companies in different ways. Whereas the most commonly used shareholder voting tool is remote voting, especially small shareholders are usually only able to discuss matters with corporate board members directly at shareholder meetings. The solution to these substantial problems, however, is just around the corner: blockchain technology can solve the current inefficiencies that shareholders and companies face. Using a permissioned blockchain, information can be stored in a verifiable and immutable way, with a consensus protocol tailored to its purpose. More specifically, by using permissioned blockchain technology long chains of intermediaries and shareholder inequality can be strongly diminished. The large amount of initiatives and prototypes of blockchain proxy voting and trading, including the legislative initiatives that have been initiated during the last 3 years, show the merits of using this state of the art technology.

Whether the use of blockchain technology can lead to the full integration of trading (including clearing and settlement) and the exercise of shareholder rights in a state of the art securities model depends on the willingness of parties to switch to this new technology. Further, it will require standardisation and cooperation between regulators, issuers, shareholders and auditors in order to enable a financial consumer-friendly IT-architectural system. ${ }^{103}$ Although small shareholders and institutional investors may still be sceptical about the use of blockchain to conduct a 'virtual-only' meeting, we believe that using the technology for a transparent and verifiable system of proxy voting is likely to receive large-scale support. Moreover, the Implementing Regulation of the SRD II seems to hint at this type of modern technology. The involvement of a party ('the permissioner') facilitating the switch in the market to this state of the art technology is key, but also the European Union can

Footnote 102 (continued)

30 May 2018, currently in discussion in the Finance Commission of the French Parliament (http://www. assemblee-nationale.fr/dyn/15/dossiers/alt/ratification_ordonnance_2017-1674 (25 January 2019)).

103 Financial Reporting Council (2018). 
play a pivotal role in guiding the transition towards a swift and resilient institutional blockchain shareholder ownership and engagement framework.

Currently, the European Central Securities Depositories system as organised by Regulation (EU) No. 909/2014 aims at reducing the settlement periods that cause uncertainty and increase risk, and at providing an initial book-entry recording, taking the form of immobilisation or of immediate dematerialization. This Regulation tackles settlement failures concerning the compulsory enforcement of the original agreement, but this can also be improved with blockchain technology; blockchain technology can provide a system in which the original agreement and the settlement can take place at the same time and can preclude settlement failures from occurring or at least make visible that a transaction is initiated. This kind of ledger can reduce discussions on the settlement of obligations and the emergence of rights for the buyer of the shares to a strict minimum.

The EC's FinTech Action Plan Communication of 8 March $2018^{104}$ is promising in that perspective. The EC refers to the support of the European Parliament for launching the European Financial Transparency Gateway (EFTG), a pilot project using distributed ledger technology to facilitate access to information on all listed companies on EU securities regulated markets. In combination with the aforementioned ASX system, it can be a promising start to a major turnaround for share ownership. The EC also installed the EU Blockchain Observatory and Forum in February 2018, helping the EC to explore and develop blockchain applications. We hope that it will soon result in enhancing blockchain proposals in the field of shareholder ownership and engagement.

Open Access This article is distributed under the terms of the Creative Commons Attribution 4.0 International License (http://creativecommons.org/licenses/by/4.0/), which permits unrestricted use, distribution, and reproduction in any medium, provided you give appropriate credit to the original author(s) and the source, provide a link to the Creative Commons license, and indicate if changes were made.

\section{References}

Aparicio JG (2017) Enhancing shareholder rights in intermediated securities holding structures across borders. N Y Univ J Law Bus 13(2):465-502

AST Financial (2017) AST completes successful pilot of blockchain-based solution for proxy voting, processing at volumes simulating the largest proxy campaigns. AST Financial, 13 December 2017. https://www.astfinancial.com/us-en/news-events/newsroom/news/ast-completes-successful-pilot -of-blockchain-based-solution-for-proxy-voting-processing-at-volumes-simulating-the-largest-proxy -campaigns/. Accessed 8 June 2018

ASX (2018) CHESS replacement: new scope and implementation plan. ASX Consultation Paper, April 2018. https://www.asx.com.au/documents/public-consultations/chess-replacement-new-scope-andimplementation-plan.pdf. Accessed 8 June 2018

Bajpai P (2017) How stock exchanges are experimenting with blockchain technology. Nasdaq, 12 June 2017. http://www.nasdaq.com/article/how-stock-exchanges-are-experimenting-with-blockchain -technology-cm801802. Accessed 8 June 2018

104 European Commission (2018), p 13. 
BlackRock (2017) BlackRock Investment Stewardship: Protecting our clients' assets for the long-term. https://www.blackrock.com/corporate/literature/publication/blk-profile-of-blackrock-investment -stewardship-team-work.pdf. Accessed 8 June 2018

Burgess K (2018) Market reverberates with accusations of 'empty voting'. Financial Times, 15 July 2018. https://www.ft.com/content/5dbd7d56-1256-11e8-940e-08320fc2a277. Accessed 17 July 2018

Deutsche Börse (2015) Open day 2015 blockchain technology. http://www.mds.deutsche-boerse.com/ blob/10304/649c21aa656ba788026f9d371caa557f/blockchain-technology-data.pdf. Accessed 8 June 2018

Deutsche Bundesbank (2016) Joint Deutsche Bundesbank and Deutsche Börse blockchain prototype. Deutsche Bundesbank, 28 November 2016. https://www.bundesbank.de/Redaktion/EN/Pressemitteilun gen/BBK/2016/2016_11_28_blockchain_prototype.html. Accessed 8 June 2018

ESMA (2014) Guidelines for competent authorities and UCITS management companies. ESMA/2014/937EN. ESMA, 1 August 2014. https://www.esma.europa.eu/sites/default/files/libra ry/2015/11/esma-2014-0011-01-00_en_0.pdf. Accessed 8 June 2018

Euroclear Sweden (2018) The shareholding in Sweden 2017. https://www.euroclear.com/dam/ESw/Broch ures/Documents_in_English/The-Shareholding-in-Sweden_2017.pdf. Accessed 8 June 2018

European Commission (2018) Communication from the Commission to the European Parliament, The Council, The European Central Bank, The European Economic and Social Committee and the Committee of the Regions-FinTech Action Plan: for a more competitive and innovative European financial sector. 8 March 2018. COM(2018) 109 final

Fildes N, Rovnick N, Pooley C (2018) BT cuts off Patterson to calm City. Financial Times (UK edition), 9 June 2018. https://www.ft.com/content/c03b699e-5918-11e8-bdb7-f6677d2e1ce8. Accessed 9 June 2018

Financial Reporting Council (2018) Blockchain and the future of corporate reporting-how does it measure up? June 2018. https://www.frc.org.uk/getattachment/58866565-ab3b-44d3-93e1-1ef7158968d5/Block chain-and-the-future-of-corporate-reporting-how-does-it-measure-up-(June-2018).pdf. Accessed 28 June 2018

FINRA (2015) When paper paralyzed Wall Street: remembering the 1960s paperwork crisis. FINRA, 19 Augustus 2015. https://www.finra.org/investors/when-paper-paralyzed-wall-street-remembering-1960s -paperwork-crisis. Accessed 8 June 2018

Finextra (2017) ADX showcases blockchain voting at AGMs. Finextra, 9 October 2017. https://www.finex tra.com/pressarticle/71057/adx-showcases-blockchain-voting-at-agms. Accessed 8 June 2018

Flood C (2018) Vanguard creates new European stewardship team. Financial Times, 18 February 2018. https ://www.ft.com/content/5dbd7d56-1256-11e8-940e-08320fc2a277. Accessed 8 June 2018

Fontenot LA (2017-2018) Public company virtual-only annual meetings. Bus Lawyer 73:35-51

Geis G (2018) Traceable shares and corporate law. Virginia Public Law and Legal Theory Research Paper No 2018-13. https://ssrn.com/abstract=3129042. Accessed 8 June 2018

GKN Plc (2018a) Results of the annual general meeting 3 May 2018. https://www.gkn.com/contentass ets/09904b86113048029e078b0b71e509c9/2018-agm-voting-results.pdf. Accessed 8 June 2018

GKN Plc (2018b) Annual general meeting 3 May 2018 notice of the meeting. https://www.gkn.com/globa lassets/downloads/agm-documents/agm-notice-of-meeting-2018.pdf. Accessed 8 June 2018

Ho S (2017) Canada's TMX taps blockchain for shareholder voting technology. Reuters, 6 April 2017. https ://www.reuters.com/article/cbusiness-us-tmx-grp-blockchain-idCAKBN1782BV-OCABS. Accessed 8 June 2018

Hu H, Black B (2006) Empty voting and hidden (morphable) ownership: taxonomy, implications, and reforms. Bus Lawyer 61:1011-1070

Iansiti M, Lakhani KR (2017) The truth about blockchain. Harv Bus Rev 95(1):118-127. https://hbr. org/2017/01/the-truth-about-blockchain. Accessed 8 June 2018

IBM (2017) IBM blockchain platform technical overview. November 2017. https://www-01.ibm.com/commo n/ssi/cgi-bin/ssialias?htmlfid=KUW12555USEN\&. Accessed 8 June 2018

IBM Blockchain Blog (2017) The difference between public and private blockchain. IBM, 31 May 2017. https://www.ibm.com/blogs/blockchain/2017/05/the-difference-between-public-and-private-blockchain I. Accessed 8 June 2018

Informal Company Law Expert Group (ICLEG) (2016) Report on digitalisation in company law of the Informal Company Law Expert Group. ICLEG, 24 March 2016. http://ec.europa.eu/justice/civil/files/compa ny-law/icleg-report-on-digitalisation-24-march-2016_en.pdf. Accessed 8 June 2018 
KAS Bank (2018) Blockchain technology simplifies voting rights. KAS Bank, 6 April 2018. https://www. kasbank.com/en/about-us/news/2018/blockchain-technology-simplifies-voting-rights/. Accessed 8 June 2018

Krouse S (2018) At BlackRock, Vanguard and State Street, 'engagement' has different meanings. Wall Street Journal, 20 January 2018. https://www.wsj.com/articles/at-blackrock-vanguard-and-state-street-engag ement-has-different-meanings-1516449600. Accessed 8 June 2018

Lafarre A (2017) The AGM in Europe: theory and practice of shareholder behaviour. Emerald Publishing Limited, Bingley

Lafarre A, Van der Elst C (2018) Legal tech and blockchain for corporate governance and shareholders. In: Berle A, Mak V, Tjong Tjin Tai E (eds) Research handbook on data science and law. Edward Elgar Publishing, Cheltenham, pp 153-182

Lafarre AJF, Van der Elst CF (2019) Corporate sustainability and shareholder activism in the Netherlands. In: Sjäfjell B, Bruner C (eds) Cambridge handbook of corporate law, corporate governance and sustainability. Cambridge University Press, Cambridge, UK (forthcoming)

Laster T (2016) The block chain plunger: using technology to clean up proxy plumbing and take back the vote. CII Keynote Speech, 29 September 2016. https://www.cii.org/files/09_29_16_laster_remarks.pdf. Accessed 8 June 2018

Manifest (2018) AGM resolutions: what you see may not be what you get. Manifest, 22 May 2018. https:// www.manifest.co.uk/agm-resolutions-what-you-see-may-not-be-what-you-get/. Accessed 8 June 2018

Mooney A (2017) Nuns tell companies to get real over virtual AGMs. Financial Times, 20 October 2017. https://www.ft.com/content/cce89ddc-b4eb-11e7-a398-73d59db9e399. Accessed 8 June 2018

Mooney A, Fildes N (2018) BT chief executive Gavin Patterson faces shareholder backlash. The Financial Times, 4 June 2018. https://www.ft.com/content/36c63298-65ac-11e8-90c2-9563a0613e56. Accessed 8 June 2018

Mooney A, Megaw N (2018) Santander shows potential of blockchain in company votes. Financial Times, 17 May 2018. https://www.ft.com/content/c03b699e-5918-11e8-bdb7-f6677d2e1ce8. Accessed 8 June 2018

Nasdaq (2016) Nasdaq's blockchain technology to transform the Republic of Estonia's e-residency shareholder participation. Nasdaq, 12 February 2016. http://ir.nasdaq.com/releasedetail.cfm?relea seid=954654. Accessed 8 June 2018

Nasdaq (2017) Nasdaq to deliver blockchain e-voting solution to Strate. Nasdaq, 22 November 2017. http:// www.nasdaq.com/press-release/nasdaq-to-deliver-blockchain-evoting-solution-to-strate2017112200117. Accessed 8 June 2018

NSD (2016) National Settlement Depository tested a blockchain-based e-proxy voting prototype. NSD, 28 April 2016. https://www.nsd.ru/en/press/ndenews/index.php?id36=628973. Accessed 8 June 2018

Overstock.com (2016) t0 platform successfully employed in the world's first public issuance of a blockchain equity. Overstock.com, 22 December 2016. http://investors.overstock.com/mobile.view?c=13109 $1 \& v=203 \& d=1 \& i d=2231332$. Accessed 8 June 2018

Smyth J (2017) ASX chooses blockchain for equities clearing. Financial Times, 7 December 2017. https:// www.ft.com/content/c9b86e8e-dae4-11e7-a039-c64b1c09b482. Accessed 8 June 2018

Song W (2017) Bullish on blockchain: examining Delaware's approach to distributed ledger technology in corporate governance law and beyond. Harv Bus Law Rev Online 8:9-20

State Street (2018) State Street global advisors global proxy voting and engagement principles. State Street, March 2018. https://www.ssga.com/investment-topics/environmental-social-governance/2018/03/Globa 1-Proxy-Voting-and-Engagement-Principles-2018.pdf. Accessed 8 June 2018

Tiemstra JST, De Keijzer J (2008) Algemene vergadering van aandeelhouders: hoeksteen van corporate governance of niet-representatieve formaliteit? Ondernemingsrecht 2008(54):192-197

T. Rowe Price Group (2016) T. Rowe Price to compensate clients for Dell voting error. https://www3.trowe price.com/usis/corporate/en/press/t-rowe-price-to-compensate-clients-for-dell-voting-error.html. Accessed 8 June 2018

Unidroit (2009) Legislative guide on intermediated securities. Unidroit, Rome

Van der Elst C (2014) The corporate response to shareholder activism. ERA Forum 15:229-242

Van der Elst C (2017) Answering the say for no pay. In: Vasudev PM, Watson S (eds) Innovations in corporate governance-global perspectives. Edward Elgar, Cheltenham, pp 151-190

Van der Elst C, Lafarre A (2017) Blockchain and the 21st century annual general meeting. Eur Co Law 14(4):167-176

Vanguard (2017) Investment stewardship annual report 2017. https://about.vanguard.com/investment-stewa rdship/annual-report.pdf. Accessed 8 June 2018 
Yermack D (2017) Corporate governance and blockchains. Rev Financ 21:7-31

Publisher's Note Springer Nature remains neutral with regard to jurisdictional claims in published maps and institutional affiliations. 